\title{
Impact of dental caries on preschool children's quality of life: an update*
}

\author{
Marcelo Bönecker ${ }^{(a)}$ \\ Jenny Abanto(a) \\ Gustavo Tello(a) \\ Luciana Butini Oliveira ${ }^{(b)}$ \\ (a) Disciplina de Odontopediatria, Univ de São \\ Paulo - USP, São Paulo, SP, Brazil. \\ (b) Faculdade de Odontologia, Centro de \\ Pesquisas Odontológicas São Leopoldo \\ Mandic, Campinas, SP, Brazil.
}

Abstract: The literature reports that dental caries can cause functional, physical and aesthetic impairment, often with repercussions on children's general health at an early age. Moreover, recent studies have investigated how caries lesions can compromise children's quality of life. This paper aims to describe the current situation of dental caries prevalence in children and how this oral health disease can impact their quality of life.

Descriptors: Quality of Life; Dental Caries; Child, Preschool.

\section{Introduction}

The oral health problems affecting Brazilian children have received special attention in epidemiology and contemporary dentistry. Although Brazil does not have a national epidemiological survey to identify all the basic oral health problems in children under 5 years of age, the results of some regional studies allow us to assert that the most frequent problems are dental caries lesions, ${ }^{1,2}$ traumatic lesions, ${ }^{3,4}$ and dental erosion. ${ }^{5}$

Unless a healthy lifestyle, good oral hygiene and nutrition are established, caries lesions may affect the teeth in the primary dentition, as soon as they erupt into the oral cavity. At this stage of growth and development, the most often affected teeth are the upper incisors.

Some children often have a high degree of destruction in this region. This may reduce chewing efficiency, promote parafunctional habitssuch as tongue interposition-cause loss of vertical dimension, and affect aesthetics, with intense psychological repercussions.

A healthy smile has considerable bearing on social interaction, which plays an important role in how children are seen, felt and perceived by others.

Dentofacial aesthetics is an important determinant of overall physical certify that they have no commercial or associative interest that represents a conflict of interest in connection with the manuscript.

Corresponding Author:

Marcelo Bönecker

E-mail: bonecker@usp.br

Submitted: Aug 23, 2012

Accepted for publication: Oct 16, 2012

Last revision: Nov 05, 2012 


\section{Prevalence of dental caries in children}

The SB Brazil Project conducted in 2010 reported early involvement of caries lesions. Among the children who were examined and presented caries, the mean $\mathrm{dmft}$ index for 5 -year-old children was 2.43 and $53.4 \%$, whereas the mean DMFT at 12 years of age was 2.07 and $56.5 \%$. In Brazil, there has been a trend toward a decrease in dental caries, as shown in Figure 1. Progressive national epidemiological surveys indicate that tooth decay has been declining consistently in 12 year-old children ${ }^{7-11}$ and slightly in 5 year-old children. ${ }^{9-11}$ On the other hand, data based on the last national epidemiological survey in Brazil also showed that the prevalence of untreated caries lesions in 5 year-old children is high $(80 \%)$. Therefore, it is necessary to evaluate the impact of disease on preschool children's quality of life in order to encourage dental treatment and promote better quality of life.

In Brazil, there is no data follow-up for groups of children under 5 years old. However, a decrease in caries prevalence has been observed in recent years in children under 3 years old. This finding was reached through a sequence of cross-sectional studies performed using the same methodology, in the city of Diadema. ${ }^{12}$ Nonetheless, there is no sequence of national data relating to caries and quality of life for children 5 years old or less. The prevalence of dental caries in 4-year-old children varies widely

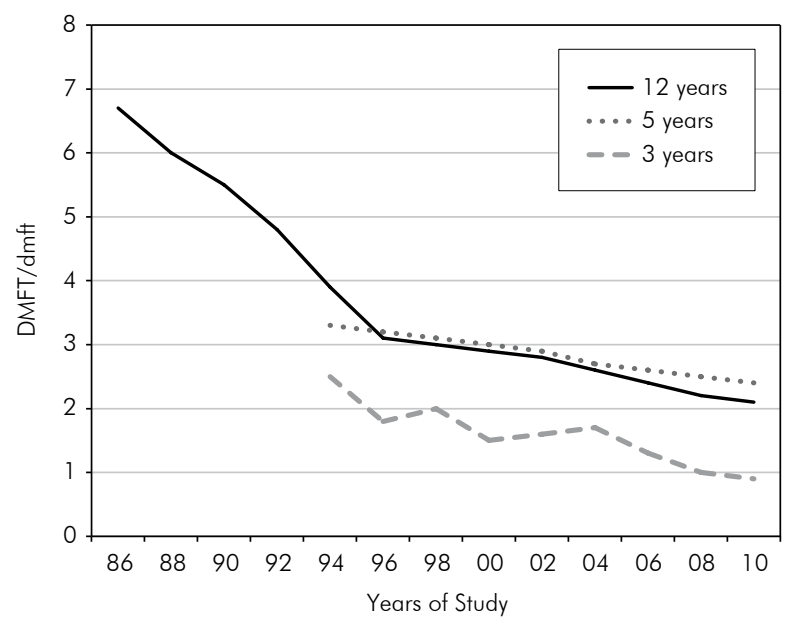

Figure 1 - Caries trend in 3-, 5- and 12-year-old Brazilian children. across countries, especially between developed and developing countries. Developing countries, such as China $^{13}(53 \%)$, India ${ }^{14}(53 \%)$ and South Africa ${ }^{15}$ $(46 \%)$, report greater caries prevalence, as compared to developed countries like England ${ }^{16}(32 \%)$ and Italy $(22 \%){ }^{17}$

Despite the lower dental caries prevalence in developed countries, the issue of quality of life related to oral health has been increasingly discussed in the literature over the last two decades.

\section{Impact of dental caries in children's quality of life}

Among the many problems compromising the oral health of child patients, tooth decay is the affection that most frequently evokes aesthetic and functional complaints in a child's clinical routine, affecting his/her quality of life. It has also been observed that the greater the number of teeth affected or lost, the greater the negative impact on a patient's quality of life.

Thus, dental treatment may offer a positive psychosocial impact on these patients, not only for recovering their oral health, but also for promoting an improvement of their quality of life.

The negative impact of caries on children's lives includes: symptoms and functional alterations, such as chewing and speech impairment, schooling factors, such as preschool absenteeism, psychological issues, such as trouble sleeping, and irritability, among other factors related to social interaction, such as smiling and refraining from speaking. School performance may also decline..$^{18-22}$

These effects are generally expressed as a cumulative experience that worsens as the disease progresses, presenting oral clinical symptoms that indirectly affect a patient's quality of life. ${ }^{18-27}$ In more severe cases, the caries disease may not only adversely influence the affected patient himself, but also interfere in his daily activities and those of others around him. ${ }^{26}$ Few studies have been conducted with children to assess how a toothache caused by caries may impact their daily activities. Some authors assert that having meals and sleeping are the most affected activities. ${ }^{28}$ It has also been estimated that sixty million school hours are lost each year due to tooth pain. ${ }^{29}$ Sur- 
veys measuring quality of life related to oral health in school children with dental caries show that life quality is strongly correlated with its negative impact on oral symptoms, followed by functional limitations, and finally its impact on emotional and social well-being. ${ }^{30}$ However, recent studies show that dental treatment in both healthy and disabled children considerably enhances their quality of life..$^{25,31,32}$

\section{Discussion}

The concept of health in regard to Health Promotion has expanded to include other issues, such as socioeconomic, environmental and behavioral factors that interfere in individual and collective health. Thus, the concept of oral health now encompasses quality of life, as well as oral symptoms, functional limitations, and emotional and social well-being, factors not considered previously. ${ }^{33}$ The indicators used in clinical dentistry have been restricted to people who notice symptoms such as pain, discomfort and aesthetic changes. ${ }^{34}$

It is not yet common practice to measure the impact that these indicators have on children's lives when performing a diagnosis or carrying out a treatment plan. Over the last two decades, there has been a substantial development of an indicator known as COHQoL - child oral-health-related quality of life. ${ }^{35}$ Currently there are some available tools that can be used to measure functional and psychosocial oral disease outcomes; most of these are targeted at adults. Since the evaluation in children should be considered differently from that in adults, the interest in assessing the impact of oral disease on quality of life in pediatric populations has increased, especially as of 2003. Children have been the major focus of public health dentistry; this concern highlights the urgent need to apply the oral-health-related quality of life concept at this stage of life. ${ }^{33}$ The responsibility for young children's health usually belongs to their parents, who are often responsible for making decisions about their health. Therefore, it is of utmost importance to evaluate parents' perception toward their children's oral health problems, including how related symptoms, diseases and treatments may influence their children's quality of life.

Evidence also suggests that early childhood caries result in parents' work absenteeism, ${ }^{33}$ since they must stay home to care for their children, or spend time and money to have the disease treated. ${ }^{28}$ Thus, these issues concerning parents must also be investigated as part of the OHQoL evaluation in younger children.

According to child development psychology, the age of six years is a landmark for inception of abstract thinking and building of one's self image. ${ }^{6,36,37}$ At this age, children start comparing their physical characteristics and personality traits with those of other children. Their ability to make judgments about their appearance, the quality of their friendships, their thoughts, their emotions and the behavior of others gradually also develops at this age. ${ }^{6}$ The idea of aesthetics linked to health now begins to be incorporated in the mind of the child, interfering with his/her concept of self-esteem. ${ }^{36}$

OHQoL measurement in preschool children involves some methodological issues, such as changes in the ability to understand the child at different ages, and difficulty in separating the child's perceptions from those of his/her parents. ${ }^{37}$ However, a number of recently developed tools have shown that, by applying an appropriate technique, questionnaires for parents could produce valid and reliable information about their children's OHQoL. ${ }^{38,39}$

The fact that the information provided by the parents complements that of the patient does not mean it is equivalent to that of the patient. ${ }^{40,41} \mathrm{To}$ day, it is highly recommended that the child's voice also be heard, insofar as it may introduce points of view different from those stated by parents. ${ }^{42,43}$ Nonetheless, only one parent-related information collecting tool ${ }^{44}$ was used to assess the impact of caries and dental trauma in 2-to-5-year-old children's OHQoL. ${ }^{25,44-47}$ Recently, the SOHO-5 (scale of oral health outcomes for 5-year-old children) was developed and validated in the United Kingdom (UK). This tool was developed to facilitate the evaluation of children's OHQoL, as reported by them and by their parents. ${ }^{48}$

ECOHIS and SOHO-5 were designed and validated to measure oral health problems that affect young children, and also call attention to children with different levels of oral health issues. A yet additional role for these tools is to evaluate and demon- 
strate possible changes in OHQoL, in both individuals and groups. ${ }^{49}$ This is the goal of future studies.

\section{Conclusion}

Whenever cases of caries lesions compromise the health of a child patient, the dentist should make use of all resources available to restore the individual to his/her previous state, recovering his/her self-esteem, and thus improving sleep quality, weight gain,

\section{References}

1. Ferreira SH, Beria JU, Kramer PF, Feldens EG, Feldens CA. Dental caries in 0- to- 5 -year-old Brazilian children: prevalence, severity, and associated factors. Int J Paediatr Dent. 2007 Jul;17(4):289-96.

2. Dini EL, Holt RD, Bedi R. Prevalence and severity of caries in 3- to 12-year-old children from three districts with different fluoridation histories in Araraquara, SP, Brazil. Community Dent Health. 1998 Mar;15(1):44-8.

3. Oliveira LB, Marcenes W, Ardenghi TM, Sheiham A, Bönecker M. Traumatic dental injuries and associated factors among Brazilian preschool children. Dent Traumatol. 2007 Apr;23(2):76-81.

4. Beltrao EM, Cavalcanti AL, Albuquerque SS, Duarte RC. Prevalence of dental trauma children aged 1-3 years in Joao Pessoa (Brazil). Eur Arch Paediatr Dent. 2007 Sep;8(3):141-3.

5. Murakami C, Oliveira LB, Sheiham A, Corrêa MSNP, Haddad $\mathrm{AE}$, Bönecker M. Risk indicators for erosive tooth wear in Brazilian preschool children. Caries Res. 2011 Mar;45(2):121-9.

6. Rebok G, Riley A, Forrest C, Starfield B, Green B, Robertson J, et al.. Elementary school-aged children's reports of their health: a cognitive interviewing study. Qual Life Res. 2001;10(1):59-70.

7. Brasil. Ministério da Saúde. Coordenação Nacional de Saúde Bucal. Condições de saúde bucal da população brasileira. Resultados principais. Brasília (DF): Ministério da Saúde; 2010 [cited 2012 Aug 15]. Available from: http://189.28.128.100/ dab/docs/geral/projeto_sb2010_relatorio_final.pdf.

8. Brasil. Ministério da Saúde. Levantamento Epidemiológico em Saúde Bucal: Brasil, zona urbana, 1986. Divisão Nacional de Saúde Bucal; fundação Serviços de Saúde Pública. Brasília (DF): Centro de Documentação do Ministério da Saúde; 1988. $137 \mathrm{p}$.

9. Serviço Social da Indústria. Estudo epidemiológico sobre prevalência da cárie dental em crianças de 3 a 14 anos: Brasil, 1993. Brasília (DF): Sesi-DN; 1996. 52 p.

10. Brasil. Coordenação de Saúde Bucal do Ministério da Saúde. Levantamento Epidemiológico em saúde Bucal - Cárie dental - Brasil - 1996. Brasília (DF): Coordenação de Saúde Bucal do Ministério da Saúde; 1998.102 p. and pain levels. Recognition of dental treatment not only by the parents but also by the children may also be rewarding for professionals.

A healthy smile is certainly one way of developing interpersonal relationships and self-esteem. Therefore, rehabilitation and clinical treatment follow-up are necessary, insofar as oral health plays an important role in the overall life of children and in their emotional well-being.

11. Brasil. Ministério da Saúde. Coordenação Nacional de Saúde Bucal. Projeto SB Brasil 2003: condições de saúde bucal da população brasileira 2002-2003. Resultados principais. Brasília (DF): Ministério da Saúde; 2005.67 p. (Série C. Projetos, Programas e Relatórios). [cited 2012 Aug 15]. Available from: http://dtr2001.saude.gov.br/editora/produtos/livros/ pdf/05_0053_M.pdf.

12. Bönecker M, Ardenghi TM, Oliveira LB, Sheiham A, Marcenes W. Trends in dental caries in 1- to 4-year-old children in a Brazilian city between 1997 and 2008. Int J Paediatr Dent. 2010 Mar;20(2):125-31.

13. Shang XH, Li DL, Huang Y, Chen H, Sun RP. Prevalence of dental caries among preschool children in Shanghe County of Shandong Province and relevant prevention and treatment strategies. Chin Med J (Engl). 2008 Nov 20;121(22):2246-9.

14. Simratvir M, Moghe GA, Thomas AM, Singh N, Chopra S. Evaluation of caries experience in 3-6-year-old children, and dental attitudes amongst the caregivers in the Ludhiana city. J Indian Soc Pedod Prev Dent. 2009 Jul-Sep;27(3):164-9.

15. Cleaton-Jones P, Williams S, Green C, Fatti P. Dental caries rates in primary teeth in 2002, and caries surveillance trends 1981-2002, in a South African city. Community Dent Health. 2008 Jun;25(2):79-83.

16. Pitts NB, Boyles J, Nugent ZJ, Thomas N, Pine CM. The dental caries experience of 5 -year-old children in Great Britain (2005/6). Surveys co-ordinated by the British Association for the study of community dentistry. Community Dent Health. 2007 Mar;24(1):59-63.

17. Campus G, Solinas G, Strohmenger L, Cagetti MG, Senna A, Minelli L, et al.. National pathfinder survey on children's oral health in Italy: pattern and severity of caries disease in 4-year-olds. Caries Res. 2009;43(2):155-62.

18. Oliveira LB, Sheiham A, Bönecker M. Exploring the association of dental caries with social factors and nutritional status in Brazilian preschool children. Eur J Oral Sci. 2008 Feb;116(1):37-43.

19. Acs G, Shulman R, Ng MW, Chussid S. The effect of dental rehabilitation on the body weight of children with early childhood caries. Pediatr Dent. 1999 Mar-Apr;21(2):109-13. 
20. Feitosa S, Colares V, Pinkham J. The psychosocial effects of severe caries in 4-year-old children in Recife, Pernambuco, Brazil. Cad Saude Publica. 2005 Sep-Oct;21(5):1550-6.

21. Filstrup SL, Briskie D, Fonseca M, Lawrence L, Wandera A, Inglehart MR. Early childhood caries and quality of life: child and parent perspectives. Pediatr Dent. 2003 SepOct;25(5):431-40.

22. Aces G, Pretzer S, Foley M, Ng MW. Perceived outcomes and parental satisfaction following dental rehabilitation under general anesthesia. Pediatr Dent. 2001 Sep-Oct; 23(5):419-23.

23. Ayhan H, Suskan E, Yildirim S. The effect of nursing or rampant caries on height, body weight and head circumference. J Clin Pediatr Dent. 1996;20(3):209-12.

24. Low W, Tan S, Schwartz S. The effect of severe caries on the quality of life in young children. Pediatr Dent. 1999 SepOct;21(6):325-6.

25. Abanto J, Carvalho TS, Mendes FM, Wanderley MT, Bönecker M, Raggio DP. Impact of oral diseases and disorders on oral health-related quality of life of preschool children. Community Dent Oral Epidemiol. 2011 Apr;39(2):105-14.

26. Abanto J, Paiva SM, Raggio DP, Celiberti P, Aldrigui JM, Bönecker $M$. The impact of dental caries and trauma in children on family quality of life. Community Dent Oral Epidemiol. 2012 Aug;40(4):323-31.

27. Shepherd MA, Nadanovsky P, Sheiham A. The prevalence and impact of dental pain in 8-year-old school children in Harrow, England.Br Dent J. 1999 Jul;187(1):38-41.

28. Gift HC, Reisine ST, Larach DC. The social impact of dental problems and visits. Am J Public Health. 1992 Dec;82(12):1663-8.

29. Do LG, Spencer A. Oral health-related quality of life of children by dental caries and fluorosis experience. J Public Health Dent. 2007;67(3):132-9.

30. Baens-Ferrer C, Roseman MM, Dumas HM, Haley SM. Parental perceptions of oral health-related quality of life for children with special needs: impact of oral rehabilitation under general anesthesia. Pediatr Dent. 2005 Mar-Apr;27(2):137-42.

31. Thomas CW, Primosch RE. Changes in incremental weight and well-being of children with rampant caries following complete dental rehabilitation. Pediatr Dent. 2002 MarApr;24(2):109-13.

32. Abanto J, Carvalho TS, Bönecker M, Ortega AO, Ciamponi AL, Raggio DP. Parental reports of the oral health-related quality of life of children with cerebral palsy. BMC Oral Health. 2012 Jun;12(1):15. [Epub ahead of print].

33. Jokovic A, Locker D, Stephens M, Kenny D, Tompson B, Guyatt G. Validity and reliability of a questionnaire for measuring child oral-health-related quality of life. J Dent Res. 2002 Jul;81(7):459-63.

34. Marques LS, Ramos-Jorge ML, Paiva SM, Pordeus IA. Malocclusion: esthetic impact and quality of life among Brazilian schoolchildren. Am J Orthod Dentofacial Orthop. 2006 Mar;129(3):424-7.
35. Robinson P, Gibson B, Khan F, Birnbaum W. Validity of two oral health-related quality of life measures. Community Dent Oral Epidemiol. 2003 Apr;31(2):90-9.

36. Casamassimo PS. Relationships between oral and systemic health. Pediatr Clin North Am. 2000 Oct;47(5):1149-57.

37. Barbosa TS, Gavião MB. Oral health-related quality of life in children: part III. Is there agreement between parents in rating their children's oral health-related quality of life? A systematic review. Int J Dent Hyg. 2008 May; 6(2):108-13.

38. Jokovic A, Locker D, Stephens M, Kenny D, Tompson B, Guyatt, G. Measuring parental perceptions of child oral health-related quality of life. J Public Health Dent. 2003 Spring;63(2):67-72.

39. Pahel BT, Rozier RG, Slade GD. Parental perceptions of children's oral health: the Early Childhood Oral Health Impact Scale (ECOHIS). Health Qual Life Outcomes. 2007 Jan;5:6.

40. Achenbach TM, McConaughy SH, Howell CT. Child/adolescent behavioral and emotional problems: Implications of cross-informant correlations for situational specificity. Psychol Bull. 1987 Mar;101(2):213-32.

41. Sprangers MAG, Aaronson NK. The role of health care providers and significant others in evaluating the quality of life of patients with chronic disease: a review. J Clin Epidemiol. 1992 Jul;45(7):743-60.

42. Varni JW, Burwinkle TM, Lane MM. Health-related quality of life measurement in pediatric clinical practice: An appraisal and precept for future research and application. Health Qual Life Outcomes. 2005 May 16;3:34.

43. Jokovic A, Locker D, Guyatt G. How well do parents know their children? Implications for proxy reporting of child healthrelated quality of life. Qual Life Res. 2004 Sep;13(7):1297-307.

44. Aldrigui JM, Abanto J, Carvalho TS, Mendes FM, Wanderley MT, Bönecker M, et al.. Impact of traumatic dental injuries and malocclusions on quality of life of young children. Health Qual Life Outcomes. 2011 Sep;24;9:78.

45. Wong HM, McGrath CP, King NM, Lo EC. Oral healthrelated quality of life in Hong Kong preschool children. Caries Res. 2011;45(4):370-6.

46. Gradella CM, Bernabé E, Bönecker M, Oliveira LB. Caries prevalence and severity, and quality of life in Brazilian 2- to 4-year-old children. Community Dent Oral Epidemiol. 2011 Dec;39(6):498-504.

47. Goettems ML, Ardenghi TM, Romano AR, Demarco FF, Torriani DD. Influence of maternal dental anxiety on oral healthrelated quality of life of preschool children. Qual Life Res. 2011 Aug;20(6):951-9.

48. Tsakos G, Blair YI, Yusuf H, Wright W, Watt RG, Macpherson LM. Developing a new self-reported scale of oral health outcomes for 5-year-old children (SOHO-5). Health Qual Life Outcomes. 2012 Jun 7;10:62.

49. Li S, Malkinson S, Veronneau J, Allison PJ. Testing responsiveness to change for the early childhood oral health impact scale (ECOHIS). Community Dent Oral Epidemiol. 2008 Dec;36(6):542-8. 